\title{
Investigating Groundwater Quality in the Flood Prone Neighborhood Area in Malaysia
}

\author{
Nasir Nayan, Yazid Saleh, Mohmadisa Hashim, Hanifah Mahat and Koh Liew See \\ Universiti Pendidikan Sultan Idris, Malaysia
}

Received: 2018-07-13 Accepted: 2019-05-03

\author{
Keywords: \\ ground water, \\ monsoon, \\ water quality
}

Corespondent Email: nasir@fsk.upsi.edu.my

\begin{abstract}
The purpose of this study is to compare the quality of groundwater during wet and dry seasons in Malaysia especially in Kuala Krai District which frequently involved in annual monsoon floods and the question whether the wells can be used during floods as well as an alternative source when there are no floods. Six sampling stations were selected using six main parameters which included DO, pH, BOD, COD, TSS and NH3N. The assessment was conducted based on the standards set by Malaysian INWQS and the classification of WQI. The results of the analysis showed that most of the water samples taken during the wet season had concentration values that did not meet the DOE standards such as the DO, BOD, and NH3N parameters. Based on the WQI classification, majority stations during the wet season were in moderately contaminated except for station T6 which was clean. On the contrary, during a dry season were found to be clean except for station $\mathrm{T} 1$ which was moderately contaminated.
\end{abstract}

(c) 2019 by the authors. This article is an open access article distributed under the terms and conditions of the Creative Commons Attribution(CC BY NC) licensehttps://creativecommons.org/licenses/by-nc/4.0

\section{Introduction}

Flood is a common phenomenon in the area of trophic such as in Malaysia and Indonesia. Beside the fast flood, monsoon flood had occurred yearly and the impact to a people depend on the flood magnitude. The higher magnitude normally will be calculated based on the flood impacted area where the bigger area normally will get more people affected. Normally during the monsoon flood, people will be move out from their flooded house and will be placed in the temporary shelter known as temporary flood evacuation centre in the much higher ground. Normally the centre is the high rise building such as schools. Moreover during the flood, people will have difficulties to get the water supply for domestic use. For this reason, the research has been done and the result been presented in this article to investigate the probability to use groundwater reside in the well around the flood area for people to use it in daily chores. Groundwater is one of the main sources of freshwater stored in aquifers through penetration process or known as infiltration process (Nyanganji et al., 2011; Chin, 2006). This water source is widely consumed by people for domestic, industrial and agricultural purposes such as in the United States, Pakistan, Nigeria, Bangladesh, Africa and India, which approximately $40 \%$ of drinking water was from the groundwater, with $97 \%$ of villagers consumed it as drinking water and about $30-40 \%$ of it was used for agricultural purposes. Therefore, groundwater is a valuable water source and should be protected against any pollution. However, human activity factors had led to poor groundwater quality, such as excessive exploitation, agriculture, industry, and farming. In addition, natural factors had also caused groundwater to be exposed to various concentrations of chemical compounds derived from the geological origin (Sanaullah et al., 2016). Therefore, water quality assessment plays an important role in ensuring that the groundwater is maintained and safe for use by the residents whether during the wet or dry seasons.

In Malaysia, Kelantan is a state that often experiences water supply disruption causing most residents to rely on groundwater for daily activities especially in the district of Kuala Krai. The situation gets worse when Kuala Krai is hit by floods during the monsoon season as residents who are affected by floods will have difficulties in obtaining clean water sources. This situation is caused by the damage factor in the water supply facilities submerged by floods or the water supply system is discontinued which resulted in the water supply cannot be channeled to the residents. The increase in flood water can cause damage to water supply infrastructures such as pumps and water treatment equipment (McCluskey, 2001). This damage further affects the health of the residents and increases the risk of spreading water borne diseases during floods due to the difficulty in obtaining clean drinking water (Bariweni et al., 2012; Shimi et al., 2010).

As a result, water quality assessment has become an important issue in groundwater survey where groundwater sources are potential to be used as domestic sources (Subramani et al., 2005; Nagaraju et al., 2014) whether during the wet or dry seasons. This is because the consumption of groundwater that is contaminated with impurities may contribute to an 


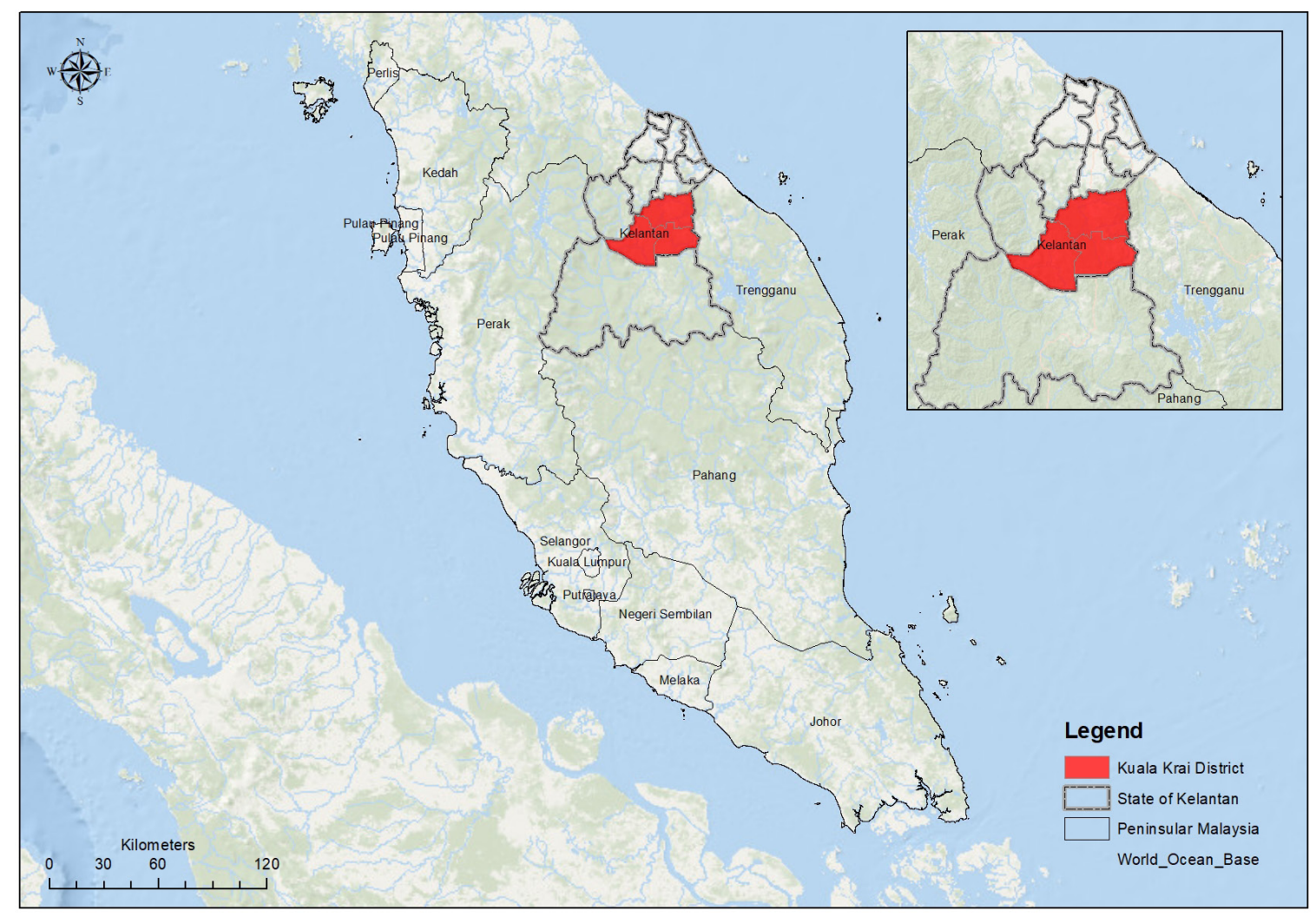

Figure 1. Study area

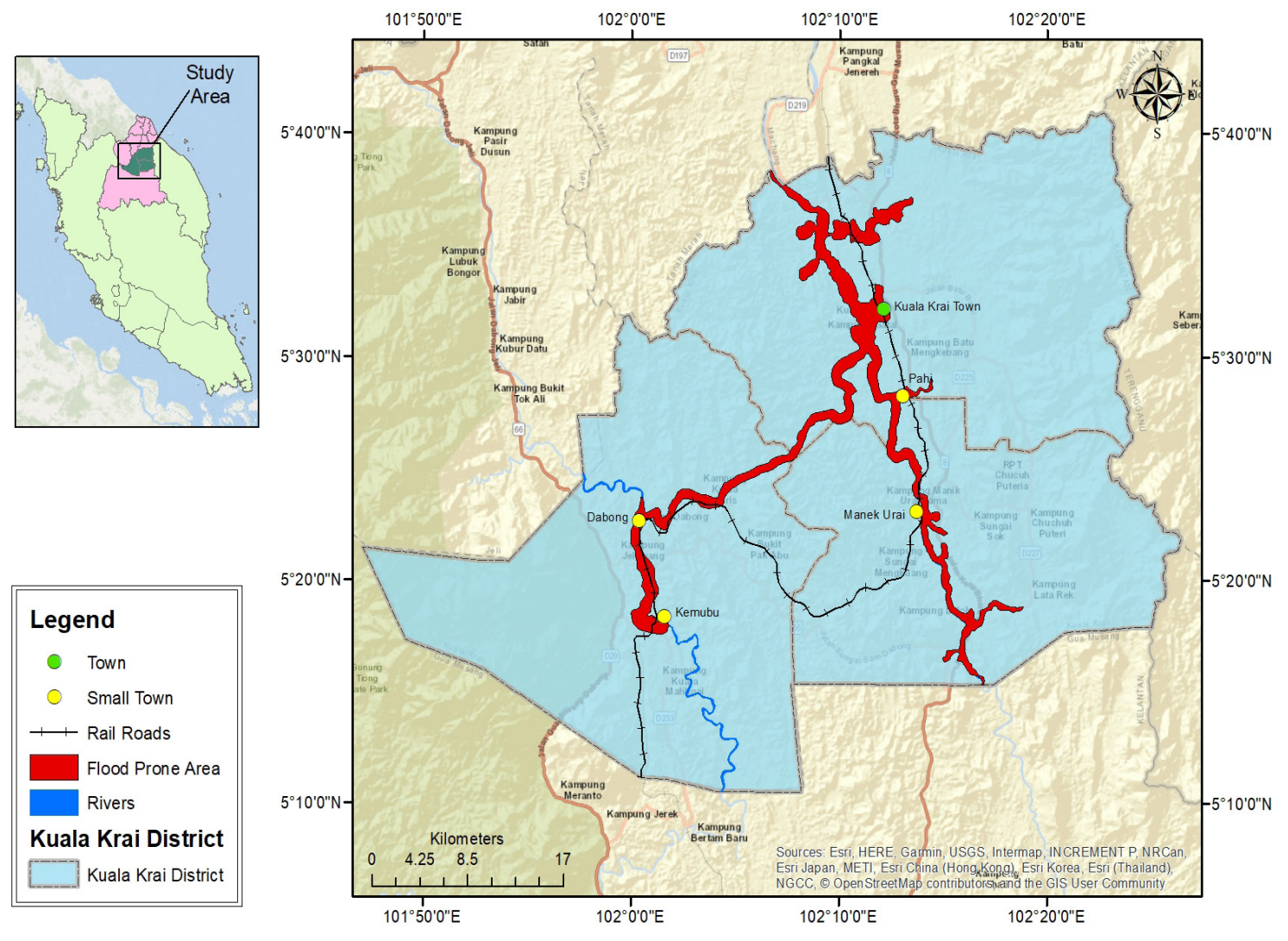

Figure 2. Flood prone areas in Kuala Krai District 
increase in water borne diseases such as cholera, skin diseases, diarrhea, dysentery, and typhoid and so on. Other than that, contaminated groundwater also causes a decline in drinking water quality, loss of water supply, the high cost of treatment (Balachandar et al., 2010). Therefore, the objective of this study is compare the quality of groundwater during the wet and dry seasons in Kuala Krai district.

This study was conducted in Kuala Krai, Kelantan which was located on the East Coast of Peninsular Malaysia. This area consists of three sub districts which include Batu Mengkebang, Olak Jeram and Dabong (Figure 1). Batu Mengkebang District is the most developed area compared to the other districts as there is Kuala Krai Town which is the focal point of the local population.

In the aspect of landform, Kuala Krai district is categorized as hilly areas. The west and east borders of Kuala Krai district are highland areas with a height of more than 300 meters and less than 100 meters in Kuala Krai Town (Department of Town and Country Planning, 2011). The highest peak in Kuala Krai district is the summit of Mount Stong with an altitude of 1,800 meters. Therefore, areas that are often vulnerable to floods are Kuala Krai Town, Pahi, Manek Urai, Lela Jasa and Dabong as these are the low areas along the Kelantan River. The main factor that causes flooding in the areas was heavy rain during the monsoon season causing the overflow of Kelantan River, Lebir River and Galas River (Figure 2).

\section{The Methods}

Sampling stations

This study was focused on four selected relief centers in Kuala Krai based on the two main criteria which are the affected relief centers during the floods and the highest number of the victim, between 400 to 500 people. Then, the location of the wells was determined based on the nearest distance between the well and the selected relief center, not submerged by flood water and was an open well. There were six well water observation stations for the four selected relief centers as in Table 1. Figure 3 shows the location of the selected flood victim relief centers and the well water stations (T1-T6).

This study was in the form of exploratory research design to find out and explore new ideas about the problems of the studied water sources. Field study method was used in this study to observe the quality of groundwater. The observations were done during the wet season (December 2016-January 2017) and the dry season (May 2017-June 2017). Water quality observation technique had involved in-situ observations and was sent to the laboratory to be analysed. Among the in-situ observation parameters were $\mathrm{pH}$, dissolved oxygen (DO) and temperature using YSI Multi Parameter System. While other parameters were sent to the laboratory for analyses on turbidity, chemical oxygen requirements (COD), biochemical oxygen requirements (BOD), ammonia nitrogen $(\mathrm{NH} 3 \mathrm{~N})$ and suspended solids (SS).

Well water sampling technique was done using a bucket at 0.5 metres from the surface of the well water which was practised by most researchers such as Wang et al. (2011); Sundaram et al. (2009); American Public Health Association (2005) and Chilton (2006) as well as overseas researchers in their study by collecting well water samples at a depth of 0.5 metres from well water surface. Besides that, there were several steps in the preservation of well water samples to prevent changes to the contents of the water samples when transported to the laboratory. During the filling of the water sample into HDPE bottle, the formation of air bubbles was avoided and preserved by using aluminium paper.

Table 1. List of Wells Sampling Stations

\begin{tabular}{|c|c|c|c|c|c|}
\hline Sub district & $\begin{array}{l}\text { Flood victim } \\
\text { center }\end{array}$ & Villages affected & Station & Latitude & Longitude \\
\hline \multirow[t]{2}{*}{ Batu Mengkebang } & $\begin{array}{l}\text { SMK Sultan } \\
\text { Yahya Petra II }\end{array}$ & Kg. Keroh & T 1 & $\begin{array}{l}5^{\circ} 30^{\prime} \\
51.3^{\prime \prime}\end{array}$ & $102^{\circ} 11^{\prime} 54.66^{\prime \prime}$ \\
\hline & & $\begin{array}{l}\text { Kg. Batu } \\
\text { Mengkebang }\end{array}$ & Т 2 & $\begin{array}{l}5^{\circ} 30^{\prime} \\
51.3^{\prime \prime}\end{array}$ & $102^{\circ} 16^{\prime} 22.7^{\prime \prime}$ \\
\hline \multirow[t]{4}{*}{ Olak Jeram } & $\begin{array}{l}\text { SMK Manek } \\
\text { Urai Lama }\end{array}$ & Lepan Meranti & Т 3 & $\begin{array}{l}5^{\circ} 19^{\prime} \\
22.1^{\prime \prime}\end{array}$ & $102^{\circ} 15^{\prime} 45^{\prime \prime}$ \\
\hline & & Kg. Budi & T 4 & $\begin{array}{l}5^{\circ} 19^{\prime} \\
57.5^{\prime \prime}\end{array}$ & $102^{\circ} 16^{\prime} 49.6^{\prime \prime}$ \\
\hline & SMK Laloh & Lepan Meranti & Т 3 & $\begin{array}{l}5^{\circ} 19^{\prime} \\
22.1^{\prime \prime}\end{array}$ & $102^{\circ} 15^{\prime} 45^{\prime \prime}$ \\
\hline & & Kg. Budi & T 4 & $\begin{array}{l}5^{\circ} 19^{\prime} \\
57.5^{\prime \prime}\end{array}$ & $102^{\circ} 16^{\prime} 49.6^{\prime \prime}$ \\
\hline \multirow[t]{2}{*}{ Dabong } & SK Kuala Gris & $\begin{array}{l}\text { Kg. Jelawang } \\
\text { Tengah }\end{array}$ & T 5 & $\begin{array}{l}5^{\circ} 20^{\prime} \\
45.65^{\prime \prime}\end{array}$ & $101^{\circ} 58^{\prime} 57.13^{\prime \prime}$ \\
\hline & & Kg. Durian Hijau & T 6 & $\begin{array}{l}5^{\circ} 20^{\prime} \\
26.88^{\prime \prime}\end{array}$ & $101^{\circ} 58^{\prime} 58.32^{\prime \prime}$ \\
\hline
\end{tabular}




\begin{tabular}{|c|c|c|c|}
\hline Class & WQI $(\%)$ & Status & The uses \\
\hline I & $>92.7$ & Very good & Suitable for drinking water supply, almost need no water treatment. \\
\hline IIA/IIB & $76.5-92.7$ & Good & $\begin{array}{l}\text { A good source for drinking water supply, normal water treatment } \\
\text { is needed. A good source for recreational uses which water contact } \\
\text { needed. }\end{array}$ \\
\hline III & $51.9-76.5$ & Moderate & Full treatment is needed and source for drinking water. \\
\hline IV & $31-51.9$ & Polluted & Suitable for drainage uses. \\
\hline $\mathrm{V}$ & $<30$ & Highly polluted & Not suitable for any uses. \\
\hline
\end{tabular}

Source: DOE (2015)

The purpose of aluminium paper wrapping was to delay biological activity and reduce the physical and chemical changes of water (Saeed \& Attaullah, 2014; Margaret, 2014). Then, the water samples were stored in an ice box containing ice at $4^{\circ} \mathrm{C}$.

This study used descriptive analysis to compare the quality of groundwater during wet and dry seasons. Among the descriptive analyses used were minimum, maximum and percentage change. The study also used the Water Quality Index (WQI) analysis which includes six parameters of Sub-Indeks (SI) based on the Malaysian Interim National Water Quality Standard (INWQS) standards set by the Department of Environment (DOE) in classifying water quality status. This standard is used by DOE in monitoring and controlling the quality of water so that water pollution can be controlled. The classification of water quality status was determined using the following WQI specific formulae:

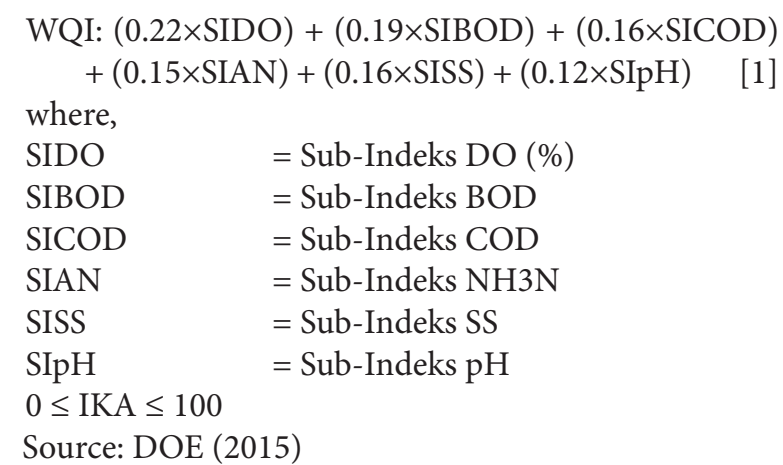

The formulae involved six main parameters namely as DO, BOD, COD, NH3N, SS, and $\mathrm{pH}$. The sub-index of all parameters and WQI been calculated with the calculation of river water quality status done in Microsoft Office Excel version 2007 in the Department of Environmental (DOE) template forms. Values taken from the template, the water quality class has been defining the five WQI classes such as Class 1- very good (>92.7), Class IIA/IIB - good (76.5 - 92.7), Class III - Intermediate (51.9 - 76.5), Class IV - Polluted (31 - 51.9) and Class V - Extremely polluted (<30) (Table 2).

\section{Results and Discussion}

Water quality assessment for groundwater by parameters

Figure 4 shows the concentration values of DO, $\mathrm{pH}, \mathrm{BOD}, \mathrm{COD}, \mathrm{NH} 3 \mathrm{~N}, \mathrm{SS}$ of each observation station. The groundwater quality assessment is based on the Interim National Water Quality Standards set by the DOE. The dissolved oxygen (DO) is the measure of the amount of free oxygen found in water when it comes in contact with air in the atmosphere (DID, 2009; Nurain \& Ang, 2015). Based on the standard value set by DOE (2015), a good DO value is $7 \mathrm{mg} / \mathrm{l}$ and above. However, DO test results in Figure 4a show that all of the water samples during the wet and dry seasons are below the standards set by the DOE, during the wet season were at $1.83 \mathrm{mg} / \mathrm{l}$ to $2.51 \mathrm{mg} / \mathrm{l}$ and during the dry season at $1.83 \mathrm{mg} / \mathrm{l}$ to $4.76 \mathrm{mg} / \mathrm{l}$ (Figure $4 \mathrm{a}$ ). This is because groundwater quality is influenced by the presence of pollutants from the domestic waste of the nearby residential (Nurain \& Ang, 2015).

The $\mathrm{pH}$ value is the most important parameter in measuring the level of acidity and alkalinity of groundwater. Measurement of $\mathrm{pH}$ is based on a scale of 0 to 14 where the value of 7 is considered neutral (good). The pH value set by DOE (2015) is between 6.5 and 8.5. Based on Figure 4b, the observation results show that most of the water samples during the wet and dry seasons do not meet the standards set by DOE where during the wet season the values were between 5.23 and 6.21 and during the dry season between 5.15 and 6.15. This condition indicates that the well water during the wet and dry seasons was slightly acidic. However, there is one station with a $\mathrm{pH}$ value that meets the standard of dry season which is the T4 station with a $\mathrm{pH}$ value of 6.86 .

In addition, biochemical oxygen demand (BOD) test is important in monitoring water quality as it serves as a measurement of the amount of oxygen used by bacteria during biological processes for decomposition of organic matter in water (Nasir et al., 2012 ). According to DOE (2015), a good water BOD value should be less than $1 \mathrm{mg} / \mathrm{l}$. Based on Figure $3 \mathrm{c}$, the BOD concentration values during the wet season for each observation station were at $0.18 \mathrm{mg} / \mathrm{l}$ to $4.94 \mathrm{mg} / \mathrm{l}$. The stations that meet the DOE standards are T3 $(0.18 \mathrm{mg} / \mathrm{l})$, T5 $(0.76 \mathrm{mg} / \mathrm{l})$ and T6 $(0.70 \mathrm{mg} / \mathrm{l})$. 


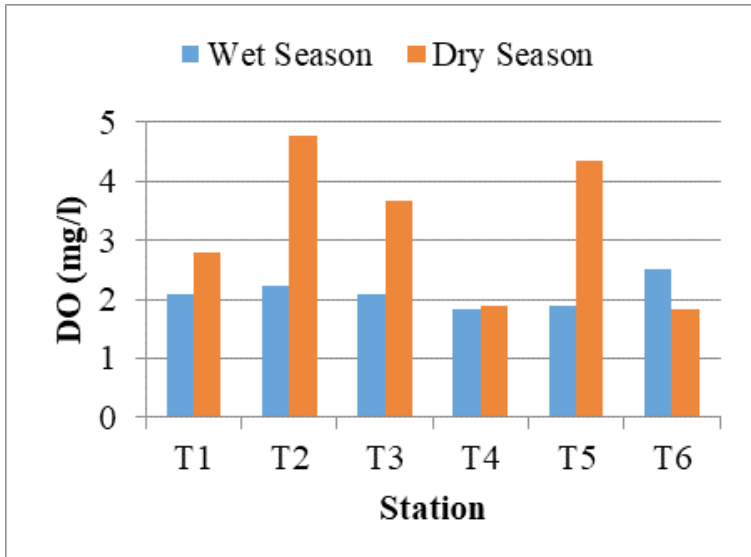

(a)

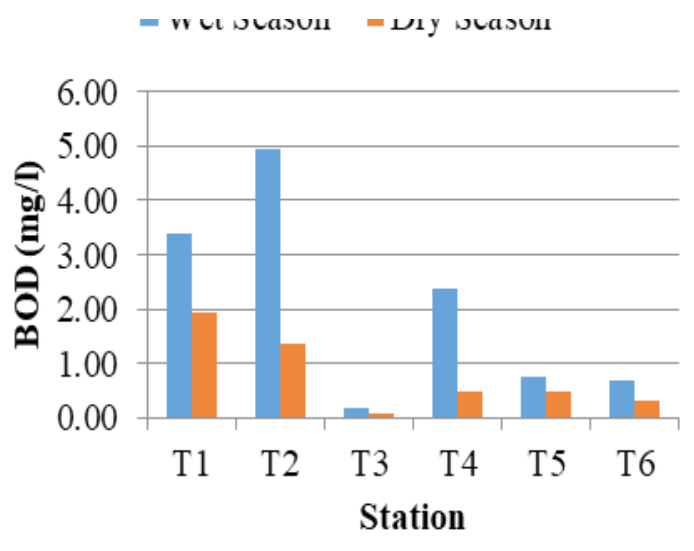

(c)

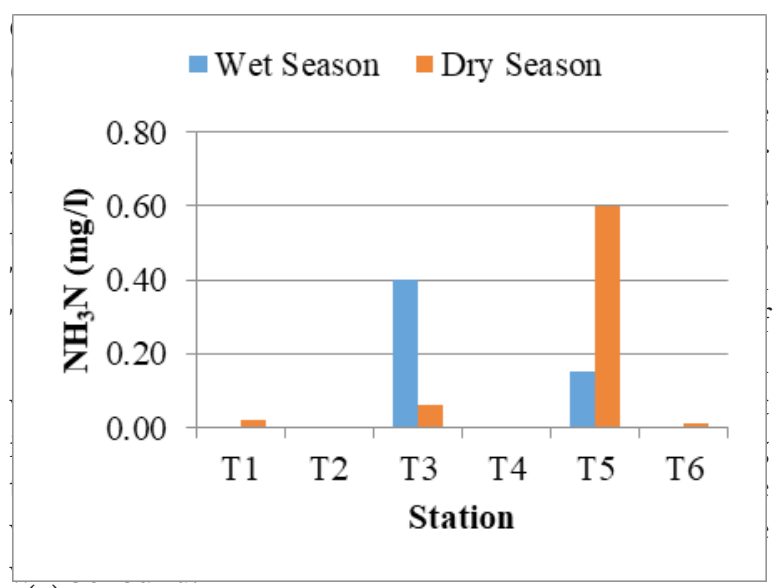

(e)

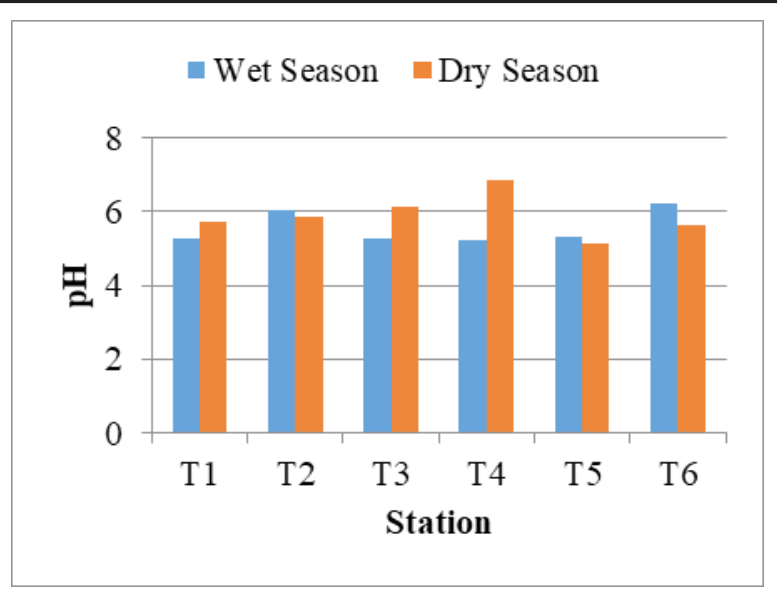

(b)

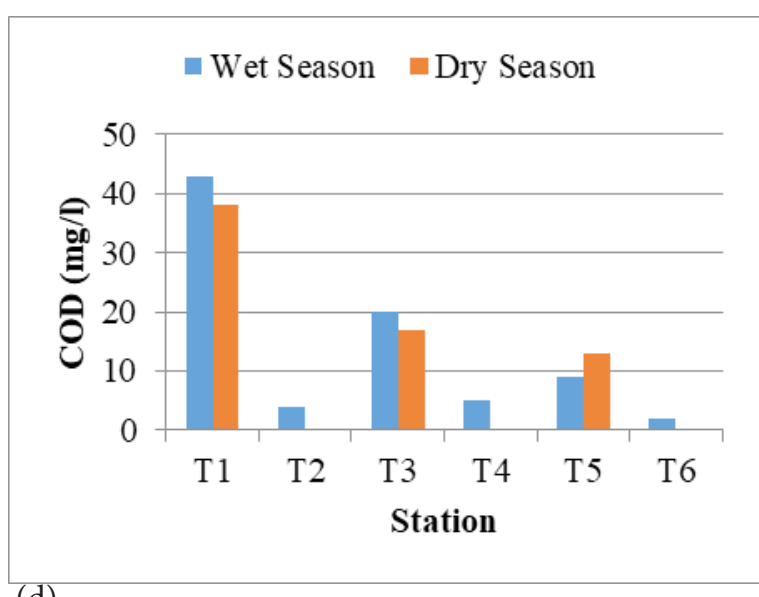

(d)

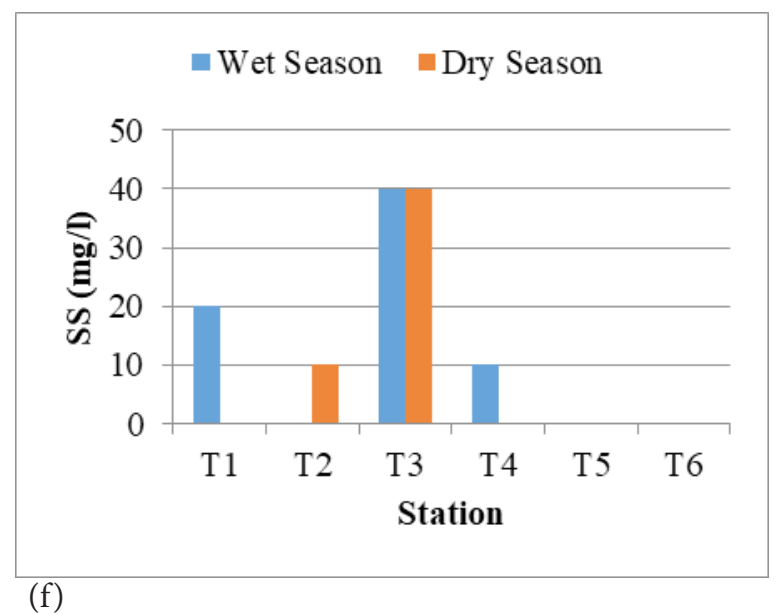

Figure. 4 Concentration value of (a) DO, (b) pH (c) BOD, (d) COD (e) NH3N and (f) SS during wet and dry season by stations

As for Chemical Oxygen Demand (COD) parameter, it is the amount of oxygen required for the oxidation of a compound material (Nurain \& Ang, 2015). Based on the DOE standards (2015), a good water COD value should be below $10 \mathrm{mg} / \mathrm{l}$. The COD test results in Figure 4d show that COD concentration values during the wet season are at $2 \mathrm{mg} / \mathrm{l}$ to $43 \mathrm{mg} / \mathrm{l}$. Four observation stations had low COD concentrations and met the DOE standards which were T2 $(4 \mathrm{mg} / \mathrm{l})$, T4 (5mg/l), T5 (9mg/l) and T6 (2mg/l), while two observation stations with high COD concentrations which were T1 (43mg/l) and T3 (20mg/l). The values of COD concentration during the dry season were at $0 \mathrm{mg} / \mathrm{l}$ to $38 \mathrm{mg} / \mathrm{l}$. Stations T2, T4 and T6 did not show any presence of COD contamination, while other stations recorded concentrations above the standards set by the DOE which was T1 $(38 \mathrm{mg} / \mathrm{l}), \mathrm{T} 3(17 \mathrm{mg} / \mathrm{l})$ and T5 $(13 \mathrm{mg} / \mathrm{l})$. High COD values were due to the presence of pollutants from chemical waste disposal (Nurain \& Ang, 2015). Most of the well are situated at the populate area in the village surrounding of natural 
but $\mathrm{T} 1$ and $\mathrm{T} 3$ were located at the urban area where chemical waste suspected come from.

As for $\mathrm{NH} 3 \mathrm{~N}$ parameter, it was measured to determine whether the water source was contaminated with human and animal wastes which resulting from microbiological activity in groundwater (Nasir, et al., 2009). Based on the standards, a good NH3N value is less than $0.1 \mathrm{mg} / \mathrm{l}$ (DOE, 2015). Figure $4 \mathrm{e}$ shows the values of $\mathrm{NH} 3 \mathrm{~N}$ during the wet season which were at $0.0 \mathrm{mg} / \mathrm{l}$ to $0.40 \mathrm{mg} / \mathrm{l}$. There were four stations that recorded zero values which were $\mathrm{T} 1, \mathrm{~T} 2, \mathrm{~T} 4$, and $\mathrm{T} 6$, while other stations recorded $\mathrm{NH} 3 \mathrm{~N}$ concentrations above the limit set by DOE which was T3 $(0.40 \mathrm{mg} / \mathrm{l})$ and T5 $(0.15 \mathrm{mg} / \mathrm{l})$. Since T1 is located in the urban area, it is understood that the value will be high coming from the domestic waste. But for the T5, where it located in the village surround with the agriculture and the high value suspected came from the agriculture fertilizer. During the dry season, NH3N values were at $0.0 \mathrm{mg} / \mathrm{l}$ to $0.60 \mathrm{mg} / \mathrm{l}$. All stations recorded values below the standards set by the DOE except for station T5 which recorded the highest $\mathrm{NH} 3 \mathrm{~N}$ concentration during the dry season of $0.60 \mathrm{mg} / \mathrm{l}$ which is came from the influence of agriculture fertilizer such as palm oil. High $\mathrm{NH} 3 \mathrm{~N}$ values are typically influenced by the use of plant fertilizers (agriculture), animal feces and domestic wastewater (Nurain \& Ang, 2015).

In addition, suspended solids (SS) parameter involves measuring of the dryness and weight of particles sized larger than $0.001 \mathrm{~mm}$ (Nurain \& Ang, 2015). The level of measurement level value of net SS is less than 25mg/l (DOE, 2015). Figure $4 \mathrm{f}$ shows that the SS values during the wet and dry seasons were $0 \mathrm{mg} / \mathrm{l}$ to $40 \mathrm{mg} / \mathrm{l}$. Most stations recorded SS concentrations below $25 \mathrm{mg} / \mathrm{l}$ and met the DOE standards which include T1,
T2, T4, T5 and T6 except for station T3 which recorded high concentration during the wet and dry seasons at $40 \mathrm{mg} / \mathrm{l}$. The presence of high SS in wells was due to the rain which had caused surface runoff carrying suspended solids into the well water during the wet season. The presence of SS during the dry season was caused by domestic activity involving the use of water near the edge of the well causing the water runway to carry suspended solids into the well.

\section{Water Quality Index (WQI)}

The location of wells has been identified to contribute to the volume concentration value in every water quality parameter such as in 5.1 topic. Station located in the centre of urban such as T1, T2 and T3 will tend to give a higher value of pollutants such as BOD, COD and NH3N. While some of the station located out of urban and located at the palm oil farming area also give some high value in water quality parameters such as NH3N at the station T5. To formulate the water quality index such as in the Table 2 either the water quality in every station either good or not to be used for domestic purpose in the evacuation centre a calculation has been done with the formulae 1 . The SI is a short form for sub-index and it occur for all water quality parameters with the SI short form placed in front of the parameter names such as SIDO is for Sub-Index for dissolved oxygen. Table 3 shows the values of SI, WQI, classes, and water quality status of each well water observation station for the wet season. The result of the analysis shows that only station T6 was in class II which is classified as clean with a WQI value of 80.99 percent. While the other stations were in class III which is classified as moderately contaminated and that include stations T1, T2, T3, T4 and T5 where WQI values were

Table 3. Value of Wells SI, WQI, Classes and Water Quality Status in Wet Season

\begin{tabular}{llllllllll}
\hline Station & SIDO & SIBOD & SICOD & SIAN & SISS & SIPH & WQI & Class & Status \\
\hline T1 & 17.30 & 86.06 & 50.72 & 100.50 & 86.17 & 65.62 & 65.17 & III & Moderate contamination \\
T2 & 19.10 & 79.50 & 93.78 & 100.50 & 97.50 & 91.34 & 75.95 & III & Moderate contamination \\
T3 & 17.07 & 99.64 & 72.50 & 66.75 & 76.40 & 65.98 & 64.44 & III & Moderate contamination \\
T4 & 14.67 & 90.29 & 92.45 & 100.50 & 91.63 & 64.56 & 72.81 & III & Moderate contamination \\
T5 & 16.02 & 97.19 & 87.13 & 84.75 & 97.50 & 67.41 & 72.33 & III & Moderate contamination \\
T6 & 23.25 & 97.44 & 96.44 & 100.50 & 97.50 & 93.83 & 80.99 & II & Clean \\
\hline
\end{tabular}

Table 4. Value of Wells SI, WQI, Classes and Water Quality Status in Dry Season

\begin{tabular}{llllllllll}
\hline Station & SIDO & SIBOD & SICOD & SIAN & SISS & SIPH & WQI & Class & Status \\
\hline T1 & 28.05 & 92.19 & 55.20 & 98.40 & 97.50 & 86.22 & 73.23 & III & Moderate contamination \\
T2 & 62.96 & 94.65 & 99.10 & 100.50 & 91.63 & 88.93 & 88.10 & II & Clean \\
T3 & 45.56 & 100.02 & 76.49 & 94.20 & 76.40 & 93.05 & 78.78 & II & Clean \\
T4 & 13.47 & 98.37 & 99.10 & 100.50 & 97.50 & 99.24 & 80.09 & II & Clean \\
T5 & 59.30 & 98.37 & 81.81 & 59.65 & 97.50 & 61.76 & 76.79 & II & Clean \\
T6 & 14.67 & 99.00 & 99.10 & 99.45 & 97.50 & 84.04 & 78.50 & II & Clean \\
\hline
\end{tabular}


64.44 percent to 75.95 percent. This condition indicates that the well water sources need to undergo a complete treatment process for domestic consumption, especially for drinking.

Table 4 shows the values of SI, WQI, classes, and water quality status of each well water observation station during the dry season. The result of the study found that most well water stations were in class II which is classified as clean where the WQI values were at 76.79 percent to 88.10 percent. This condition indicates that most well water is suitable to be used as drinking water supply and regular treatment is needed. Only station T1 was in class III which is classified as moderately clean with a WQI value of 73.23 percent and needs to undergo a complete treatment process to be used as a drinking water source.

The finding of the study shows that there were significant differences in well water quality status between the wet and dry seasons. Among the stations that experienced an increase in WQI percentage were station T2 at 12.15 percent, station T3 at 14.34 percent, station $\mathrm{T} 4$ at 7.28 percent and station $\mathrm{T} 5$ at 4.46 percent. However, only station T1 experienced an increase in WQI percentage by 8.06 percent, but the quality status during the wet and dry seasons remained as moderately contaminated. While station T6 experienced a decrease in WQI percentage by 2.49 percent, but it was still clean for the people to use.

Comparative results can be concluded that the well water quality during the dry season is better than the wet season. This is due to the fact that the groundwater during the wet season was low with DO, BOD, and high with NH3N. Normally this is due to the high volume of rain which caused the surface runoff carrying pollutants into the well. Well in the urban area will have higher value in certain parameters such as DO and NH3N since the domestic waste will follow the flood and into the well. Wells in the agriculture area too, will have certain higher value parameter such as NH3N and SS where erosion took place and bringing the upper soil to the well. This condition had caused the groundwater not suitable to be used by the people of Kuala Krai during wet seasons. A full treatment process needs to be done for domestic consumption, especially for drinking. On the other hand, the groundwater during the dry season is suitable to be consumed by Kuala Krai residents as drinking water and other domestic uses. However, a regular treatment is required to ensure that the groundwater supply is safe to be used by the residents. The findings of this study have similarities with the study conducted by Pathak et al. (2011) in Kathmandu Valley, Nepal. The findings show that the groundwater quality during the wet season had higher pollution level than during dry season which was influenced by the impact of the anthropogenic activity. Similarly, a study conducted by Adekunle et al. (2007) in southwestern Nigeria found that most pollutants concentration were increased in the groundwater during wet seasons compared to dry seasons.

This condition clearly shows that the change in season can affect the concentration level of groundwater's physico-chemical properties (Idoko \& Oklo, 2012). Therefore, groundwater quality assessment is one of the important issues in groundwater survey whether it is during the wet or dry seasons. This is because polluted water is risky to the health of the population if they consume contaminated water. Laurent et al. (2010) explain that the suitability of groundwater for drinking, irrigation, and industrial purposes depend on the quality. This is because good water quality will ensure the sustainability of socioeconomic development (Ishaku, 2011). Therefore, the quality of groundwater needs to be properly maintained so that it is not polluted and does not affect the health of the people using it.

\section{Conclusion}

In conclusion, flood prone neighborhood groundwater quality in Kuala Krai District is vary, where in the wet season the water quality pretty much at the level of moderate contamination. Over 5 of 6 stations are in moderate contamination while only one at the level clean water. Of all 5 stations examined, either there are in the urban area or in the farming estate of palm oil. And the only one is situated not in the area of urban neither farming area. While during the dry season, most of the stations are in the clean status and only one station situated in the urban area detected with moderate contamination. Wells in the urban area found not suitable either in dry nor the wet season to use for water supplying. But if there are a case where the water still need to be used, then it should be underwent the filtering process. This is because groundwater is the main source of water supply to Kuala Krai residents either during the wet or dry seasons due to water supply disruptions that are often encountered by the population. In addition, groundwater needs are also important for Kuala Krai residents for economic purposes especially agricultural sector in mobilizing local area development. Therefore, regular groundwater controlling and monitoring play an important role in water sources management of an area.

\section{Acknowledgement}

The authors would like to thank and acknowledge the Universiti Pendidikan Sultan Idris and Malaysia Ministry of Higher Education for the financial support with the research grant partly used in this article (Research code: 2015-0191-106-41 TOPDOWN KPT)

\section{References}

Adekunle, I. M., Adetunji, M. T., Gbadebo, A. M., \& Banjoko, O. B. (2007). Assessment of groundwater quality in a typical rural settlement in Southwest Nigeria. International Journal of Environmental Research and 
Public Health, 4(4), 307-318.

American Public Health Association (APHA). (2005). Standard methods for the examination of water and wastewater. American Public Health Association, American Water Works Association and Water Environment Federation, Washington, DC.

Balachandar, D., Sundararaj, P., Rutharvel Murthy, K., \& Kumaraswamy, K. (2010). An investigation of groundwater quality and its suitability to irrigated agriculture in Coimbatore District, Tamil Nadu, India A GIS approach. International Journal of Environmental Sciences, 1(2), 176-190.

Bariweni, P. A., Tawari, C. C., \& Abowei, J. F. N. (2012). Some environmental effects of flooding in the Niger Delta Region of Nigeria. International Journal of Fisheries and Aquatic Sciences, 1(1), 35-46.

Chilton, J. (2006). Groundwater. In D. Chapman (Ed.), Water quality assessments: A Guide to use of Biota, sediments, and water in environmental monitoring (2nd ed.). Cambridge: UNESCO/WHO/UNEP.

Chin, D. A. (2006). Water-quality engineering in natural systems. New Jersey: John Wiley \& Sons.

Department of Environment (DOE). (2015). Laporan kualiti alam sekeliling Malaysia 2015. Selangor: Omr Press Sdn. Bhd.

Department of Irrigation and Drainage (DID). (2009). Study on the river water quality trends and indexes in Peninsular Malaysia. Water Resources Publication, No 21.

Idoko, M., \& Oklo, A. (2012). Seasonal variation in physicochemical characteristics of rural groundwater of Benue State, Nigeria. Journal of Asian Scientific Research, 2(10), 574-586.

Ishaku, J. M. (2011). Assessment of groundwater quality index for Jimeta-Yola area, Northeastern Nigeria. Journal of Geology and Mining Research, 3(9), 219-231.

Jabatan Perancangan Bandar dan Desa (JPBD). (2011). Draf rancangan tempatan Jajahan Kuala Krai 2020: Jilid I penyataan bertulis. Semenanjung Malaysia: Jabatan Perancangan Bandar dan Desa.

Laurent, M., Francois, A., \& Marie, M. J. (2010). Assessment of groundwater quality during the dry season in Southeastern Brazzaville, Congo. International Journal of Applied Biology and Pharmaceutical Technology, 1(3), 762-769.

Margaret, O. M. (2014). The menace of the recent flood of water quality and rural people in Bayelsa State. Brazilian Research Journal of Humanities, Social and Management Sciences, 7(1), 22-33.

McCluskey, J. (2001). Water supply, health, and vulnerability in floods. Waterlines, 19(3), 14-17.

Nagaraju, A., Sreedhar, Y., Kumar, K. S., Thejaswi, A., \& Sharifi, Z. (2014). Assessment of groundwater quality and evolution of hydrochemical faces around Tummalapalle Area, Cuddapah District, Andhra Pradesh, South India. Journal of Environmental Analytical Chemistry, 1(2), $1-6$.
Nasir, N., Jamaluddin, M. D. J., \& Abdul Latif, M. (2012). Trend of River Water Quality and Pollution in Coastal Zone: A Case Study of Perak State Malaysia. World Applied Sciences Journal, 19(11), 1687-1698.

Nasir, N., Mohmadisa, H., Mohd Hairy, I., \& Mohamad Suhaily Yusri, C. N. (2009). Perubahan gunatanah dan tahap kualiti air sungai di Bandaraya Ipoh, Perak. Malaysian Journal of Environmental Management, 10(2), 115-134.

Nurain, M., \& Ang, K. H. (2015). Kualiti air Sungai UTM: Satu penilaian awal berpandukan enam parameter Indeks Kualiti Air. Geografia - Malaysian Journal of Society and Space, 11(1), 107-115.

Nyanganji, J. K., Abdullahi, J., \& Noma, I. U. S. (2011). Groundwater quality and related water borne diseases in Dass Town, Bauchi State, Nigeria. Journal of Environmental Issues and Agriculture in Developing Countries, 3(2), 133-148.

Pathak, D. R., Hiratsuka, A., \& Yamashiki, Y. (2011). Influence of anthropogenic activities and seasonal variation on groundwater quality of Kathmandu Valley using multivariate statistical analysis. In Proceedings of the Symposium on Water Quality: Current Trends and Expected Climate Change Impacts (pp. 67-72).

Saeed, T. U., \& Attaullah, H. (2014). Impact of extreme floods on groundwater quality (in Pakistan). British Journal of Environment \& Climate Change, 4(1), 133-151.

Sanaullah, M., Akram, M., \& Dawood, B. (2016). Post flood water quality discrepancies in physico-chemical scenarios, Sialkot, Pakistan. International Journal of Advances in Agricultural \& Environment Engineering, 3(1), 1-5.

Shimi, A. C., Parvin, G. ., Biswas, C., \& Shaw, R. (2010). Impact and adaptation to flood: A focus on water supply, sanitation and health problems of a rural community in Bangladesh. Disaster Prevention and Management: An International Journal, 19(3), 298-313.

Subramani, T., Elango, L., \& Damodarasamy, S. R. (2005). Groundwater quality and its suitability for drinking and agricultural use in Chithar River Basin, Tamil Nadu, India. Environmental Geology, 47, 1099-1110.

Sundaram, B., Feitz, A., Caritat, P. D., Plazinska, A., Brodie, R., Coram, J., \& Ransley, T. (2009). Groundwater sampling and analysis-a field guide. Geoscience Australia, Record, 27, 95.

Wang, Q., Munoz-Carpena, R., Foster, A., \& Migliaccio, K. W. (2011). Chapter 6: Groundwater sampling. In Y. Li \& K. Migliaccio (Eds.), Water quality concepts, sampling, and analyses (pp. 73-91). United States: CRC Press. 